JMP

$28,7 / 8$

886

Received June 2011

Revised December 2011

March 2012

Accepted March 2012

\section{Hiring retirees: impact of age norms and stereotypes}

\author{
Kasia Karpinska
}

Utrecht University School of Economics, Faculty of Law, Economics and Governance, Utrecht University, Utrecht, The Netherlands and

Netherlands Interdisciplinary Demographic Institute (NIDI), The Hague, The Netherlands

\section{Kene Henkens}

Netherlands Interdisciplinary Demographic Institute (NIDI), The Hague, The Netherlands and Faculty of Social and Behavioural Sciences, Tilburg University, Tilburg, The Netherlands, and

\section{Joop Schippers}

Utrecht University School of Economics,

Faculty of Law, Economics and Governance, Utrecht University, Utrecht, The Netherlands

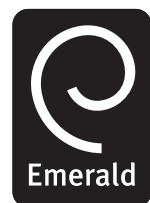

Journal of Managerial Psychology Vol. 28 No. $7 / 8,2013$ pp. $886-906$ (C) Emerald Group Publishing Limited 0268-3946

DOI 10.1108/JMP-07-2013-0223

\begin{abstract}
Purpose - This study aims to investigate the role of managers in the re-employment of early retirees and focuses on the effect of managers' age norms and stereotypes on managers' employment decisions. Design/methodology/approach - A combination of a factorial study and a survey was conducted. First, information on the age norms and stereotypes was collected. Secondly, profiles of hypothetical retired job applicants were presented to the employers, who were asked to make a specific hiring decision. The information collected during both studies was combined in the analysis and multilevel models were estimated.

Findings - The results indicate that higher age norms (defined as age at which somebody is believed to be unable to work for 20 hours a week or more) result in a higher propensity to hire an early retiree. Stereotypes, by contrast, do not influence managers' decisions. Early retirees' chances for re-employment are also related to their own circumstances (physical appearance and relevant experience) and organisational forces, as they are hired when organisations face labour force shortages.

Research limitations/implications - With the use of vignettes study the authors deal with a hypothetical hiring situation.

Originality/value - Although the effect of attitudes has been often suggested, not much empirical evidence has been presented to support this notion. This study estimates the effect of age norms and stereotypes on hiring decision.
\end{abstract}

Keywords Older workers, Recruitment, Social norms, Stereotypes

Paper type Research paper

\section{Introduction}

Changes in the population structure and the ageing workforce suggest that employers may need to retain and hire more older workers (Elster, 1989). Bridge employment,

This paper draws on data of the LISS panel of CentERdata. 
i.e. employment that occurs between career jobs and permanent retirement (Wang and Shultz, 2010), is expected to help close the gap in labour force supply that will occur along with the retirement of the baby-boomers (Wang et al., 2008). As retirement has come to be seen as a more dynamic and gradual transition from a working to a non-working life, a growing number of older workers may opt for bridge employment in the future.

Much research in the field of bridge employment has focused on older workers and their motivation, preferences and ability to extend their working career (Weckerle and Shultz, 1999; Jones and McIntosh, 2010). Those studies focus on the supply side and indicate that individual attributes like age and good health, along with attractive working conditions (such as challenging work) promote older workers' intentions of continued employment (Kim and Feldman, 2000; Wang et al., 2008). Growing evidence suggests that the share of workers willing to extend their working career is increasing (von Bonsdorff et al., 2009).

While older workers have some agency about whether to retire or to enter self-employment (Bruce et al., 2000), prospects of returning to the labour force for early retirees (i.e. individuals who exit the work force before the mandatory retirement age) are largely determined by employers and the availability of jobs in organisations (Munnell and Sass, 2008). Although managers are the ones deciding on the hiring, the demand side for older workers has not yet attracted much attention.

Karpinska et al. (2011) show that the hiring propensity of early retirees is low, also for those with a high employability. This raises the question whether the hiring of early retirees is influenced not only by their individual attributes but also by managers' dispositional attitudes towards older workers. Although early retirees are a subcategory of older workers they are likely to be similarly affected by ageist attitudes. Our study integrates these aspects of labour market participation of older workers and asks "How do ageist stereotypes and age norms, next to attributes of applicants, affect managers' propensity to hire early retirees?".

There is a wide body of literature that focuses on the general attitudes of employers. Those attitudes frame managers' perceptions of older workers and their abilities (Van Dalen et al., 2010), and can take the form of age norms and stereotypes. The concept of social norms and their impact on behaviour has been one of the paradigms of sociology for decades and has been gaining recognition in economics (Elster, 1989; Coleman, 1990). Norms as rules of behaviour coordinate interactions with others and are believed to guide individuals in social situations. Stereotypes form important cognitive tools that facilitate the information processing (Hilton and von Hippel, 1996), and as such, influence behavioural response (Bargh et al., 1996).

Although it has been suggested that both stereotypes and age norms may affect employers' behaviour (Chiu et al., 2001; Finkelstein and Burke, 1998; Lee and Clemons, 1985; Loretto et al., 2000) not much empirical evidence has been presented to support this connection. Studies on age norms in employment transitions often describe organisational age norms and factors behind them (Settersten and Hagestad, 1996; Settersten, 1998; Lawrence, 1996). Specific managerial norms and their impact on behaviour have been neglected. Similarly, while there are few studies analysing the effect of age stereotypes on attitudes towards different aspects of employment of older workers (Chiu et al., 2001; Henkens, 2005; Hassell and Perrewe, 1995), they do not focus on their impact on decisions. A number of studies used an experimental design to evaluate

\section{Hiring retirees}

887 
JMP $28,7 / 8$

888 decisions regarding older workers (in basket or audit experiments; see Bendick et al., 1997; Finkelstein et al., 1995). Yet, not many have combined those two paths to assess the possible impact of general attitudes on individual employment decisions.

Our study contributes to the existing literature in two ways. Firstly, we combine information on the demand and supply side, highlighting complexity of the hiring process. As suggested by Posthuma and Campion (2009) most studies that investigate ageist stereotypes and labour market outcomes focus on one dimension only, neglecting the organisational context. In the current work we not only estimate the effect of general attitudes (age norms and stereotypes) on hiring behaviour regarding early retirees but simultaneously we also evaluate applicants' attributes and the effect of organisational forces.

In addition, we estimate the effect of both age norms and age stereotypes on a specific decision. Liefbroer and Billari (2010) argue that although impact of age norms on human behaviour has been debated for decades now, it is still lacking an extensive empirical test. We contribute to this debate by offering an empirical test of the possible impact of general attitudes on managers' (hypothetical) hiring behaviour.

To investigate this specific employment decision, a combination of a survey and a vignette study was designed. The data for our study were collected in two stages. First we carried out the survey among managers and collected information on age norms and age-related stereotypes (Study 1). A month later, during Study 1, a vignette study among the same group of managers was conducted. A factorial design allows the exploration of actions in context and offers an opportunity to simulate employment decisions (Rossi and Anderson, 1982). All managers were asked to make hiring decisions for five hypothetical applicants.

The study was carried out in The Netherlands, where labour market policies have recently changed substantially, from encouragement of early exit to encouragement of working longer (Van Dalen and Henkens, 2002). A recent policy change assumes extending working lives until the age of 67. In 2009 fewer than 50 per cent of workers aged 55-64 was employed (Statistics Netherlands, 2009), and although workers retire later in The Netherlands than they used to, in 2010 only 27 per cent of workers retired at the statutory retirement age of 65 . Discrimination is one of the forces that are assumed to be behind this phenomenon. A substantial number of early retirees consider their transition into retirement as involuntary (van Solinge and Henkens, 2007). Koppes et al. (2009) showed that in The Netherlands age discrimination is still perceived to be substantial: the self-reported rate of age discrimination among older (55-64 years) workers is 20 per cent. Re-entry of (early) retirees is, in most cases, not restricted by labour force regulations or law (i.e. employers can hire older worker even after the age of 65). And although re-entry increases, many retirees are unsuccessful in finding a job after retirement even when shortages on the labour market are widespread (Van Dalen et al., 2009).

\section{Theory}

There are three types of factors that intertwine in the recruitment process:

(1) organisational characteristics;

(2) managers' attributes; and

(3) applicants' attributes. 
Organisational context

Organisations are goal-oriented systems that strive towards profit maximisation, continuity, and maintaining a healthy market position (Kalleberg et al., 1996). Managers in organisations are supposed to contribute to these goals by, among others, recruitment of qualified staff (Kalleberg et al., 1996). Managers are expected to react to organisational workforce shortages by choosing the best candidates from the applicant pool. Successful applicants are thus the ones who are believed to be the most capable of fulfilling the assigned tasks.

The decision regarding the hiring of early retirees is generally taken by a manager, but is always embedded in the broader context of a dynamically changing organisation. Macro-level developments (e.g. economic changes and labour-force shortages) influence managers' choices. When organisations shed jobs during an economic downturn, managers are assumed to assign less priority to hiring retired workers as it might hamper the work prospects of younger generations and conflict with norms of generational employment equity (Van Dalen and Henkens, 2002). On the other hand, managers facing structural or incidental labour-force shortages may be inclined to hire early retirees as a remedy. Hence we expect managers to be more inclined to hire early retirees when the organisation faces labour-force shortages $(H 1)$.

\section{Attributes of managers}

In the selection process, managers evaluate hiring desirability of applicants by assessing their productivity. Hiring decisions involve uncertainty, as individual productivity capabilities are not known at the time of hiring (Phelps, 1972; Spence, 1973). Managers deal with this uncertainty by evaluating a combination of observable attributes of applicants (Phelps, 1972; Spence, 1973). Employers also have access to what Phelps (1972) calls "previous statistical experience": information on how certain categories of employees tend to behave and develop. As productivity assessment is a complex information-processing task, managers apply categorisation and stereotyping as most effective cognitive tools (Van Dalen et al., 2010). Social norms are also applied in this process. We elaborate on both below.

Age norms. Social norms are customary rules of behaviour that coordinate human interaction. Norms either operate as part of actors' environment or shape individuals' predispositions (Etzioni, 2000). While the first aspect depicts external control of human behaviour with external restriction and sanctions, the latter proposes that norms are internalised and no external sanctions are necessary, as norms determine dispositions and goals (Etzioni, 2000; Horne, 2003).

The current study focused on age norms regarding employment transitions (Settersten and Hagestad, 1996). While age norms about the "right time" to retire are formally expressed in age boundaries established by public and private pension schemes, the life-course paradigm presumes that the transition from work to retirement is also influenced by informal age-graded norms (Settersten and Hagestad, 1996; Settersten, 1998; van Solinge and Henkens, 2007). We expect that the perception of the normative timetable (the proper age for retirement versus extended employment) affects, next to applicants' attributes, managers' hiring decisions. Support of older applicants' return to the labour market happens when managers believe that this is still

889 
JMP

$28,7 / 8$

890 appropriate. We hypothesise that the higher the age norm of managers regarding older workers' participation in the labour market, the more likely they are to hire an early retiree $(\mathrm{H} 2 \mathrm{a})$.

Stereotypes about older workers. While many studies demonstrate that employers often see older workers as inflexible, unwilling (or unable) to adapt to the changing work environment and less productive than their younger colleagues, the same studies confirm that older workers are valued for their trustworthiness, specific knowledge and interpersonal skills (Chiu et al., 2001; Finkelstein and Burke, 1998; Lee and Clemons, 1985; Taylor and Walker, 1998). Van Dalen et al. (2010) have captured this dual aspect of stereotypes regarding older workers' productivity. They showed that employers' attitudes towards older workers reflect two dimensions, i.e. hard and soft skills. Soft skills refer to qualities that play a role in job performance, such as commitment to the organisation, reliability and social skills. Those skills can be characterised as "organisational citizenship behaviour" - pro-social behaviour that is not job-specific but which is important for the broader organisational environment (Van Dalen et al., 2010; Ng and Feldman, 2008). Hard skills, on the contrary, reflect mental and physical capacity, willingness to learn new skills and adapt to new technologies, and flexibility. Although very different, both types of skills contribute to employees' productivity. Therefore we expect more positive perceptions of older workers' soft and hard skills will lead to a greater propensity of managers to hire early retirees $(H 2 b)$.

\section{Applicants' attributes}

An important aspect of hiring decisions is the evaluation of an applicant's attributes. Four issues are important here:

(1) human capital;

(2) health condition;

(3) flexibility; and

(4) social capital.

Human capital is a set of skills that is embodied in the ability to perform labour and to produce economic value. In line with human capital theory (Becker, 1975), individuals' investments in human capital are made during the person's educational career, although the skills and experience that is built up over a long working career have a strong influence on the individual's productivity in different roles (Thurow, 1975; Eijs and Heijke, 2000). Thurow (1975) found that managers take into account potential training cost differences and favour candidates who require less training. The costs of hiring an early retiree, whose skills and experience are in alignment with the job requirements are significantly lower than for those without the matching skills. Therefore we expect that relevant experience of early retirees increases the likelihood of successful application $(H 3 a)$.

The human capital of early retirees is likely to become more obsolete with the length of their retirement. Various studies show that employers perceive obsolete skills to go hand-in-hand with lower productivity (Taylor and Walker, 1994; Remery et al. 2003). This, in turn, will result in less support for hiring an early retiree. Therefore we expect that time in retirement reduces chances for re-entry into the labour market $(H 3 b)$. 
Poor health puts worker productivity at risk and casts doubts on performance continuity. As health status is hardly known during the application process, managers may refer to observable attributes. A more energetic appearance can sway managers towards hiring an older worker, as this impression contradicts stereotypical images of older inactive persons with a deteriorated health (Berger, 2009). We therefore predict that the hiring chances of early retirees are higher for those applicants who appear energetic $(H 3 c)$.

Another important factor is applicants' flexibility. As organisations may require short-term or project-based support, staff who accept being called into work only as needed (DiNatale, 2001) are preferred, and are thus more likely to be hired. There is some evidence that employers are prone to offer older workers part-time, flexible positions (Taylor, 2008). On-call arrangements in different forms (from fixed hours to part-time employment) are attractive to organisations because they enable dynamic staffing needs to be met without the commitment of permanent employment. Therefore we predict that acceptance of flexible appointments increases early retirees' chances for employment $(H 3 d)$.

Also importantly, applicants' social capital can have an impact on their hiring success. Helpful networks provide information on job openings and can be a source of valuable recommendations. Marsden and Garman (2001) indicate that employers use referrals in the staffing process, as they lower hiring costs and offer rich and trustworthy information. Employers put more trust in the recommendations offered by their contacts, as these contacts act as a guarantee; their reputation is at stake if they provide false or unreliable information (Marsden and Garman, 2001). Hence we expect that the hiring chances of early retirees rise with recommendations, especially if the recommending party is a business contact of the manager $(H 3 e)$.

In the complexity of real life situations the above mentioned groups of factors will interact with each other. One might assume that an organisational context frames managers' decisions strongly. When organisations are shedding jobs, the impact of negative age norms and stereotypes may be activated more strongly, while in time of shortages in the labour market, their effect may be slumbering and applicants' characteristics will be decisive in the recruitment process. Similarly, organisations active in different fields will have different requirements regarding older workers and their employment; as in some sectors human capital will weigh more, in others physical fitness will be critical. Consequently, employment decisions will be affected differently.

\section{Data and methods}

For this study we used a multi-method approach, combining survey research (Study 1) with a factorial study (Study 2). First a survey was administered to managers and one month later the same managers were approached again to complete a vignette study. By introducing a monthly gap between the studies we limited the risk of bias related to potential carryover effects (Leeuw et al., 2008). Moreover, this approach, with a semi-panel design, is well suited to analyse the effect of stereotypes and norms on (hypothetical) behaviour. Liefbroer and Billari (2010) suggested that to properly analyse the effect of norms on behaviour, the perception of norms needs to be observed before the actual behaviour.

We collected the data using the LISS panel (Longitudinal Internet Studies for the Social Sciences of Tilburg University; see www.lissdata.n1/lissdata/). LISS is an

\section{Hiring retirees}

891 
JMP

$28,7 / 8$

892 internet panel that consists of 5,000 households, comprising 8,000 individuals. All individuals were selected based on a true probability sample of households drawn from the population register by Statistics Netherlands.

\section{Study 1}

During Study 1, a battery of questions on stereotypes regarding older workers, age norms, and background characteristics was distributed to LISS respondents who held managerial positions during the time of the study. The data were collected in April 2010.

Participants. Based on the question "Do you supervise others?", a total of 700 LISS members (managers) were approached. The response rate for Study 1 was 73.6 per cent $(n=515)$. Although the study was aimed at different-level managers in organisations, not all of the respondents satisfied this condition. Further selection based on the question "What is your current occupation?" eliminated 186 non-managers from the sample. The final sample consisted of 238 managers. Three categories of managers are represented according to the LISS panel distinction[1]:

(1) higher supervisory positions (manager, director, owner of large company, supervisory civil servant; $n=99$ );

(2) intermediate supervisory or commercial positions (head representative, department manager, shopkeeper; $n=99) ;$ and

(3) supervisory manual workers $(n=40)$.

The sample consisted of 182 males and 56 females and the mean age of respondents was 45.3 (range $24-65, \mathrm{SD}=9.45$ ). For details see Table I.

Measurements. Age norm is based on the open question "At what age do you consider a person too old to work in your organisation for 20 hours a week or more?". The answers ranged from 40 to 100 . To avoid potential problems with outliers, the answers were truncated and ranged from 50 to 80 . The mean age was 64.7 years with a $\mathrm{SD}$ of 5.9. Also alternative coding of the age norm were tested, but as median and mode values of age norm were not affected by the coding. For the distribution of the answers see Figure 1.

Stereotype variables are based on two questions:

(1) "To what extent do the following characteristics apply to workers aged 60 or older?"; and

(2) "To what extent do the following characteristics apply to workers aged 35 and younger?".

The characteristics presented in both cases were:

- flexibility;

- social skills;

- commitment to organisation;

- creativity;

- management skills;

- reliability; 


\begin{tabular}{|c|c|c|c|c|c|}
\hline & Minimum & Maximum & $\begin{array}{c}\text { Mean/ } \\
\text { percentage }\end{array}$ & $\mathrm{SD}$ & \multirow{4}{*}{893} \\
\hline \multicolumn{6}{|l|}{ Dependent variable } \\
\hline Hiring chances & 1 & 11 & 4.15 & 0.06 & \\
\hline Independent variables & & & & & \\
\hline Stereotypes & & & & & \\
\hline Hard qualities & 1 & 4 & 0.68 & 0.27 & \\
\hline Soft qualities & 1 & 4 & 1.16 & 0.41 & \\
\hline Age norm & 50 & 80 & 64.5 & 6.04 & \\
\hline \multicolumn{6}{|l|}{ Characteristics of respondents } \\
\hline \multicolumn{6}{|l|}{ Managerial position } \\
\hline Higher supervisory positions & 0 & 1 & 41.5 & & \\
\hline Intermediate supervisory or commercial positions & 0 & 1 & 41.5 & & \\
\hline Supervisory manual workers & 0 & 1 & 16.8 & & \\
\hline Age (years) & 24 & 65 & 45.3 & 9.4 & \\
\hline Gender (male- reference category) & 0 & 1 & 76.4 & & \\
\hline Education (years) & 8 & 18 & 15.5 & 2.55 & \\
\hline \multicolumn{6}{|l|}{ Job level of subordinates } \\
\hline Manual & 0 & 1 & 19.7 & & \\
\hline Intermediary administrative & 0 & 1 & 47.8 & & \\
\hline Professional & 0 & 1 & 32.2 & & \\
\hline Size of organisation & 10 & 10,000 & 375.8 & $1,048.54$ & \\
\hline \multicolumn{6}{|l|}{ Sector } \\
\hline Industry & 0 & 1 & 26.4 & & \multirow{5}{*}{$\begin{array}{r}\text { Table I. } \\
\text { Descriptive statistics of } \\
\text { the sample used in } \\
\text { the data }\end{array}$} \\
\hline Services & 0 & 1 & 38.8 & & \\
\hline Public & 0 & 1 & 34.8 & & \\
\hline Note: $n=238$ & & & & & \\
\hline Source: LISS panel study & & & & & \\
\hline
\end{tabular}

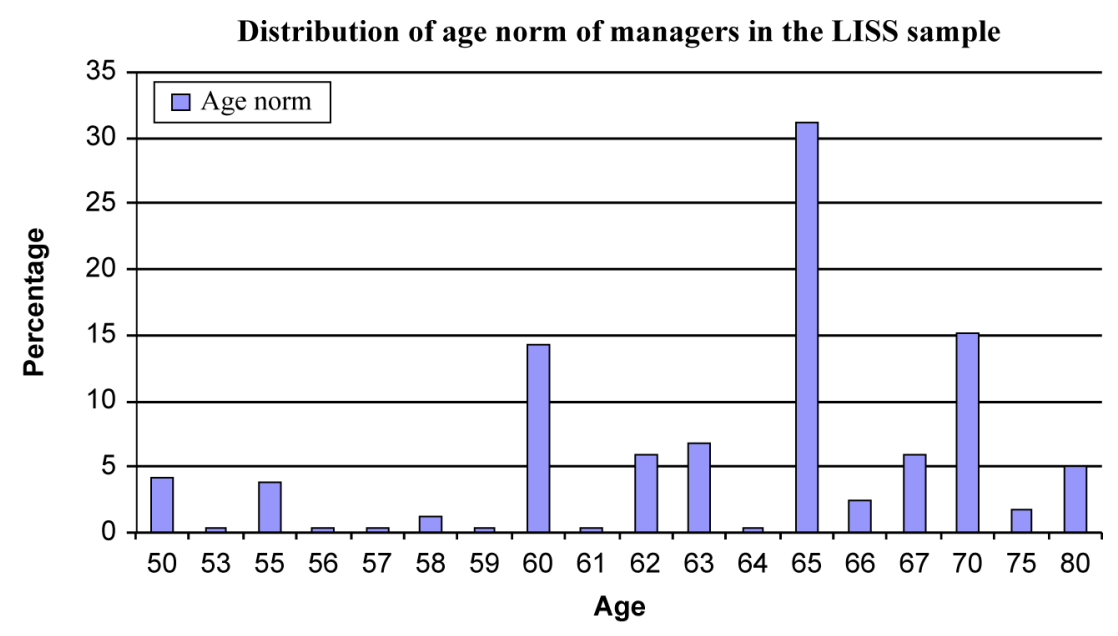

Source: LISS panel study

Figure 1.

The distribution of the age norm among managers in the LISS sample 
JMP

$28,7 / 8$

894
- willingness to learn;

- physical capacity;

- resistance to stress; and

- new technology skills.

Two factors were selected based on the factor analysis, namely soft and hard skills (Van Dalen et al., 2010). Relative scores scales (level to which those characteristics apply to older workers as compared to their younger counterparts) were computed. The soft skills scale consists of the following four items:

(1) social skills;

(2) commitment to organisation;

(3) management skills; and

(4) reliability (range 1-4; Cronbach's $\alpha=0.859$ ).

The mean value exceeds $1(\mathrm{M}=1.16)$, implying that workers aged 60 and more were perceived to possess those skills to a greater degree than younger workers. The hard skills scale is based on these items:

- creativity;

- flexibility;

- willingness to learn;

- physical capacity;

- resistance to stress; and

- new technology skills (range 1-4; Cronbach's $\alpha=0.839$ ).

The hard skills scale is lower than $1(\mathrm{M}=0.68)$ meaning that managers consider those skills as more applicable to workers aged 35 and younger than to older workers.

As both age norms and age-related stereotypes reflect managers' attitudes towards older workers, we assessed their correlation to rule out multicolinearity. The results indicate that measures of attitudes towards older workers were weakly correlated; the correlation between age norm and the soft qualities scale was $0.157(p<0.001)$ and between age norms and the hard qualities scale it was $0.126(\phi<0.001)$.

During Study 1 also information on the control variables was collected. Settersten and Hagestad (1996) suggest that age norms may vary not only across different contexts but also across occupations. This variable job level of subordinates was based on managers' answers to the open question "What is the occupation that you supervise most frequently?". We constructed three variables representing occupations. In the first step all occupations were coded according to the occupational codes of Statistics Netherlands (Standaard Beroepenclassificatie, 2010), arriving at five categories of occupations that were then limited to three categories:

(1) professional occupations;

(2) administrative positions; and

(3) manual occupations.

Details regarding the coding are available upon request. 
Other control variables were respondents' gender and respondents' age. Sector of the organisation was based on the question "In which sector is your company operating?”. Following the European Commission division of sectors, three categories were constructed:

(1) industry;

(2) services; and

(3) public.

Comparison with Eurostat statistics (European Commission, 2006) revealed that the data are representative for the sector distribution in The Netherlands.

Study 2

Study 2 consisted of a vignette survey, which is a method intended for the investigation of human actions. The basic item of the survey is a vignette, which is a short description of a situation or a person, generated by combining characteristics randomly manipulated by the researcher (Ganong and Coleman, 2006; Wallander, 2009).

Participants. For Study 2, all respondents who participated in the first round were contacted and a total of 238 questionnaires were filled in completely. The response rate for Study 2 was 82.3 per cent. In Study 2 each manager judged five vignettes, resulting in a total of 1,190 vignettes.

Measurements. In our study, hypothetical retired job applicants were described by several individual characteristics and the hiring decision was placed in a specific organisational context.

The vignette characteristics were:

- organisation characteristics (facing structural labour force shortages, incidental labour force shortages, no labour force shortages, need for downsizing);

- experience in a similar position (yes/no);

- availability (full-time only, part-time, fixed hours, flexible appointment);

- length of retirement (applicant retired a month ago, half a year ago, one-and-a-half years ago);

- physical appearance (appears vital/does not appear vital); and

- was recommended (by a business partner, by a colleague or no recommendation).

In the vignettes we also included applicant's age (58, 62 and 65) and gender (male/female). Given all possible combinations of the variables and their respective levels, the universe of 3,456 unique vignettes was created (i.e. $4 \times 3 \times 2 \times 2 \times 4 \times 3 \times 2 \times 3$; for details see Table II). None of the vignettes contained impossible combination of the factors. All the variables measured in Study 2 were included in the analysis as dummy variables, so the weights estimated for each variable are comparable.

In contrast with a factorial design in which all possible combinations are evaluated, in a vignette survey only a random selection from the universe of vignettes is judged by respondents (Wallander, 2009). In our study, each participant received a random sample of five vignettes (random selection with replacement). Each rater was required to rate each vignette on an 11-point scale, ranging from 1 (hiring very undesirable) to 11 (hiring very desirable). For an example of a vignette used in the study, see Figure 2. 
JMP

$28,7 / 8$

\section{6}

Table II.

Characteristics as found in the vignette and the expected effects, including reference categories

\begin{tabular}{ll}
\hline Categories & $\begin{array}{l}\text { Expected effect on hiring } \\
\text { probability }\end{array}$ \\
\hline
\end{tabular}

Organisation

Organisational condition

Structural labour force shortages Incidental labour force + shortages

No labour force shortages +

Need for downsizing Reference category

Applicants

Age (years)

58

62

65

Gender

Male

Female

Experience in similar position

Yes

Availability

No

Full-time only

Part-time

Fixed hours

Flexible appointment

Last worked

One month ago

Half a year ago

One-and-a-half years ago

Physical appearance

Energetic

Not very energetic

A business partner

A colleague

No specific recommendation
$+$

$+$

Reference category

$+$

Reference category

$+$

Reference category

Reference category

$+$

$+$

$+$

Reference category

$-$

$-$

$+$

Reference category

$+$

$+$

Reference category

Source: LISS panel study

\section{Analysis}

In a vignette design, the unit of analysis is the vignette (Ganong and Coleman, 2006). As each manager judged five vignettes, our factorial survey data have a hierarchical structure by design and consequently, observations are not independent (Wallander, 2009). Multilevel models were applied to deal with the hierarchical structure of the data (Hox, 2002).

In total, four models were estimated. The first model - the "empty model" decomposed the variance between the two levels of analysis:

(1) level of applicants (level 1); and

(2) level of managers' level (level 2).

In Model 2 we introduced managers' age norms and stereotypes as well as control variables of managers' organisations. Models 3 and 4 introduced attributes that were included in the vignettes. Specifically, Model 3 depicts the effect of organisational context, and Model 4 also incorporates applicants' characteristics. 
Below are various descriptions of early retirees who would like to work for your organisation. Please indicate, for each profile, what is the likelihood of you being willing to hire this person for a position that you most often supervise.

\begin{tabular}{|ll|}
\hline $\begin{array}{l}\text { Context } \\
\text { Organisational condition }\end{array}$ & Structural labour force shortages \\
Applicant & \\
Age & 65 \\
Gender & Male \\
Experience in similar position & Yes \\
Availability & Fixed hours \\
Last worked & 1.5 years ago \\
Physical appearance & Energetic \\
Recommended by & A business partner \\
\hline
\end{tabular}

What is the likelihood that you would be willing to hire this person for a position that you most often supervise?

\begin{tabular}{|c|c|c|c|c|c|c|c|c|c|c|}
\hline 1 & 2 & 3 & 4 & 5 & 6 & 7 & 8 & 9 & 10 & 11 \\
\hline Hirin & , & irab & & & Neutra & & & $\mathrm{Hir}$ & very & sirable \\
\hline
\end{tabular}

\section{Results}

Table III presents the results of our analyses. Model 1 contains only fixed and random effects of the intercept. Intra-class correlation shows that this level accounts for 38.3 per cent of the total variance in hiring scores. The intercept illustrates that on average the hiring desirability was rather low and took a value of 4.1 (on a scale ranging from 1 to 11 ).

Model 2 in Table III shows the fixed effects of age norms and stereotypes on hiring decisions. Age norms did affect managers' evaluations of the hiring desirability of early retired applicants: managers who held higher age norms about appropriate time to retire were also more likely to hire an early retiree. We also tested how different dimensions of age stereotypes affected the hiring preferences of the early retirees. Contrary to our expectations, neither soft-skills nor hard-skills stereotypes affected the hiring desirability of early retirees significantly.

In this model we also controlled for the characteristics of the managers and the context of organisations they are employed in. The findings reveal that there is no significant difference between managers employed in industry or services (as compared to the reference category, public sector) in how they evaluate the hiring desirability of early retirees. Similarly, the job level of subordinates did not significantly affect managers' decisions. In the analysis we also controlled for

\section{Hiring retirees}

897

Figure 2.

Example of a vignette 


\section{JMP $28,7 / 8$}

\section{8}

Table III.

Results of the multilevel analysis of the hiring chance of early retirees

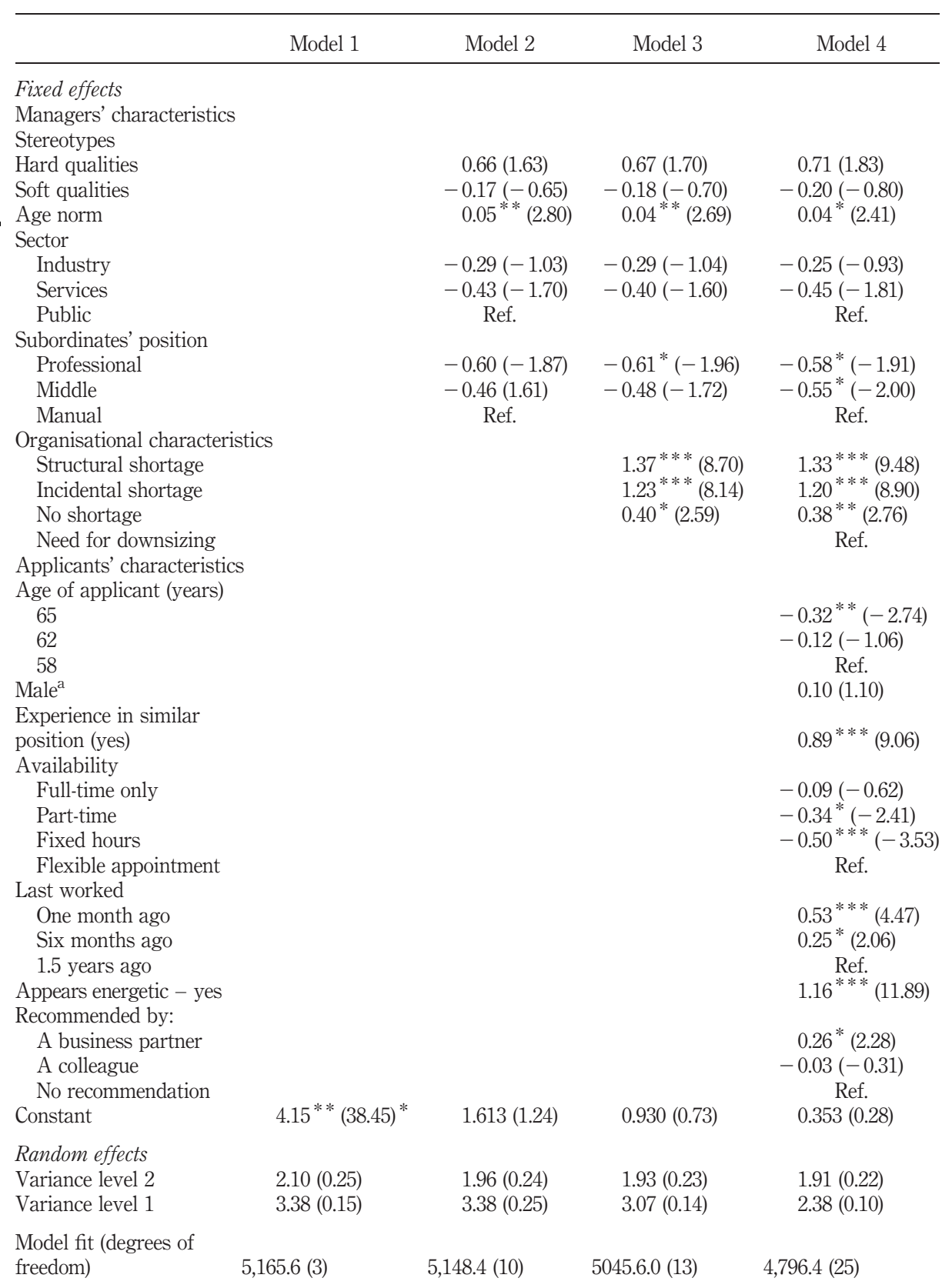

Notes: $n=1,190 ; Z$ scores for coefficients are shown in parentheses; ${ }^{2}$ reference category: female; standard error for variance components: ${ }^{*} p<0.05 ;{ }^{* *} p<0.01$; ${ }^{* * *} p<0.001$

Source: LISS panel study 
characteristics of managers. Neither managers' age nor their gender affected the hiring propensity (results not presented).

Model 3 depicts whether hiring desirability depends on organisational forces. Managers who were confronted with a structural labour force shortage during their hypothetical decision-making process were more likely to hire early retirees as compared to the reference category of organisations in need of downsizing. A similar result is observed for those organisations experiencing incidental labour force shortages. Hiring desirability drops when an organisation is in no need for new staff members, but remains positive and significant compared to the reference category.

Model 4 is the final model that includes also characteristics of applicants in the analysis. We observe that the effect of age norms remains significant even after including context information and attributes of early retirees in the analysis.

With respect to individual characteristics of early retirees, our analysis confirmed the importance of applicants' human capital on hiring chances. As expected, experience in a previous similar position increased early retirees' hiring chances. Potential decline of early retirees' human capital significantly lowered hiring dispositions of managers. For applicants who had not worked for one-and-a-half years, or even six months, hiring chances were substantially lower than for early retirees who had been absent for one month. Early retirees who presented themselves as energetic were more likely to be hired. In fact, early retirees' physical appearance was the attribute that affected managers' hiring decisions the most. While applicants' willingness to work full-time did not significantly affect managers' hiring propensity, they did prefer on-call appointment above part-time and fixed-hours appointments. A recommendation by a manager's business partner increased hiring disposition. A recommendation by a manager's colleague did not have this positive effect though.

In the analysis we also evaluated the demographic characteristics of applicants. Clearly, the oldest category of applicants faced the greatest obstacles when returning to the labour market. A 65-year-old applicant has lower hiring chances than a 58-year-old applicant. There was, however, no significant difference in how managers assessed 63-year-old applicants and their 58-year-old counterparts. Males were no more likely to be hired than females.

Our analysis also tested for the random effects of individual characteristics of early retirees, i.e. whether the effects of those characteristics differed across managers and organisations (results not shown). The analyses revealed that managers evaluated early retirees' experience and physical appearance differently. Cross-level interactions showed that managers who have higher age norms attach higher value to applicants' experience, and that older managers attach lower value to applicants' experience while assessing the hiring desirability. With respect to the physical appearance of the applicants, we expected that the effect would differ for different sectors; our results did not support that hypothesis. We were not able to distinguish which factors influence variability in physical appearance across managers, as no interactions introduced in the analysis were significant. We have also extensively tested for the differences in how various factors operate in different contexts but no significant results were found. Also, the interaction between age norms and stereotypes that was estimated to account for independence between those constructs was not significant. 
JMP

$28,7 / 8$

900

Illustration of the effects of age norms

The effect of age norms remains significant predictor of employment of early retirees, even after controlling for the effect of characteristics of organisations and applicants. To illustrate the importance of managers' age norms, for each value of age norms we predicted the hiring scores (based on Model 4 in Table III). Based on the employability of applicants (e.g. capability to gain employment, maintain it or obtain new employment; Fugate et al., 2004), we distinguished two categories of applicants:

(1) the "high" employable; and

(2) the "low" employable.

An early retiree with high employability was identified as an applicant with relevant experience, retired for a month, 58 years old and appearing energetic. An early retiree with low employability was described an applicant who did not have relevant experience, was retired for at least one-and-a-half years, was 65 years old and did not appear energetic. Figure 3 presents the effect of age norms for these two categories of applicants in two organisational situations: structural labour force shortages and need for downsizing.

The results indicate that managers' age norms are important impediments for early retirees in the labour market. For a highly employable individual applying for a position in an organisation that is in need of new staff members, we observe that the hiring desirability scores takes a value of approximately 6.7, which is the score for the lowest age norm - i.e. if a manager perceives age 50 as the limit of employment. This score is just above the neutral value of 6 . A same-category applicant dealing with managers who consider the age deadline for employment to be 80 obtains scores approaching 8. When a highly employable applicant seeks a position in an organisation shedding jobs and when a manager holds age norms at the minimum level of 65 , hiring scores peak above the neutral value of 6 and approach a value of 7 . A similar effect of age norms is observed for low-employable applicants in both organisational conditions, although in those cases the hiring score does not exceed the neutral value of 6 .

Figure 3.

Impact of the age norm on the hiring propensity of applicants characterised by high and low employability in organisations facing labour force shortage and need for downsizing
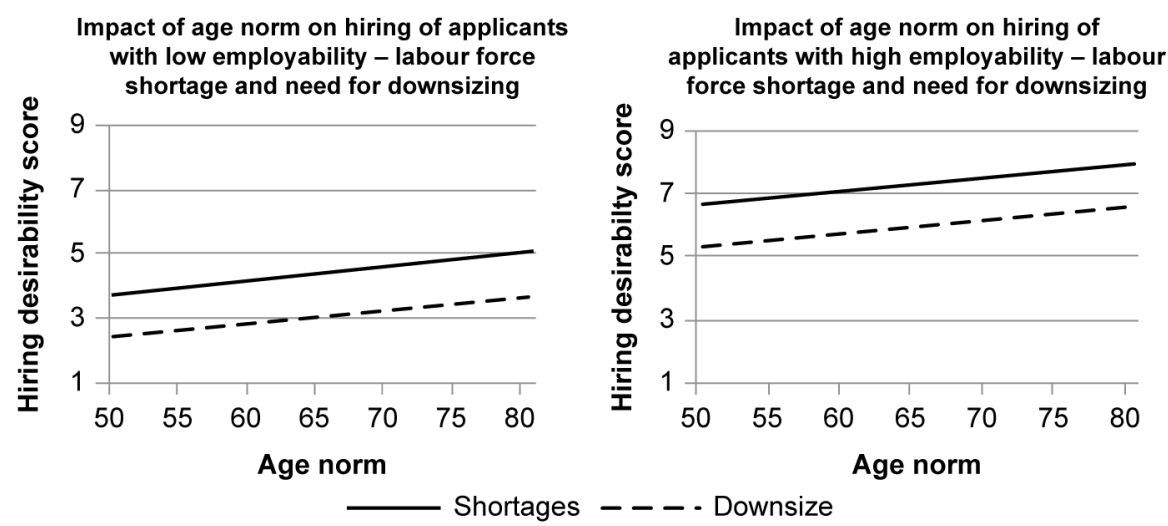

Note: $n=238$ 


\section{Discussion and conclusions}

The central issue addressed in this article was how general attitudes towards older workers influence managers' hiring decisions. We found that managers with higher age norms (i.e. when a person is too old to work for 20 hours a week) were more inclined to hire early retirees. The impact of age norms clearly identifies existence of time schedules. As indicated by life-course scholars, there are informal expectations as to when behaviour should occur (Settersten, 1998), and such norms exert significant influence on life-transition behaviour (Settersten and Hagestad, 1996; van Solinge and Henkens, 2007). Our findings thus lend support to this notion, and corroborate the link between social norms and human actions that has been suggested by many theorists (Coleman, 1990; Etzioni, 2000).

The current study does not confirm the often-suggested link between age stereotypes and employment outcomes for older workers (Chiu et al., 2001; Finkelstein and Burke, 1998; Loretto et al., 2000). It has to be noted that we focused on hiring of early retirees and not to older workers at other ages. Whether and how age stereotypes affect managers' decisions regarding different categories of older workers (unemployed, working etc.) and different types of decisions (e.g. training, retaining) are important questions for future research.

Our study also shows that although stereotypes and age norms represent general attitudes towards older workers, there is only a very weak link between them. This suggests that age norms regarding retirement transitions may not be simple representations of older workers' perceived productivity. So far not much is known about the factors that affect norms of retirement transitions. To what extent age norms are culturally determined scripts and influenced by the formal age boundaries established by public and private pension schemes, or does the organisational age structure or organisational culture also affects them, are just few of possible avenues for further inquiry. Answers to those questions can offer new insights into the link between the age norms and stereotypes and consequently, their effect on employment transitions at older ages.

Despite the effect of managerial norms, importance of personal circumstances remains crucial to application success. Physical appearance and human capital are the most important factors that increased managers' propensity to hire an early retiree. Applicants who appear vital encounter higher chances for employment. Berger (2009) showed already that many unemployed older applicants alter their physical appearance to portray a more youthful image in job interview settings to manipulate their self-presentation and sway potential employers to hire them. Our findings highlight the importance of this form of self-management on the part of older applicants, suggesting that managers indeed rely strongly on the observable attributes of early retirees when assessing their hiring desirability (Berger, 2009).

Furthermore, this study confirms the importance of human capital for the employment chances of early retirees (Karpinska et al., 2011). Applicants with relevant experience were more likely to be successful in their application process. This finding implies that occupational success of early retirees is conditional on their employability (Ekerdt, 2010), highlighting the importance of skills maintenance. The emphasis on relevant experience may also limit early retirees' opportunities to work in different occupations and sectors after they retire from their career job.

\section{Hiring retirees}

901 
JMP $28,7 / 8$

902
Some practical implications of our study can be pointed out. Firstly, our findings stress the need for awareness campaigns that will demonstrate the impact of age norms in employment process. Research has shown that executives agree that older workers are discriminated against but they did not believe that this occurred in their own organisations (Maurer et al., 2007). Secondly, training of recruiters towards more age awareness in selection procedures is necessary and can, in the long run, benefit both organisations and older workers by selecting better candidates and create diversity in teams. Preventing the bias that can be related to age norms has also implications for older workers who are employed in organisations. As managers have a rather clear idea as to when a person should leave the labour force, such attitudes can result in reduced access of older workers to training or lack of managerial support for employment until the statutory retirement age.

We conclude with some methodological remarks. In this article we combined survey research with vignette design. Factorial surveys are very suitable for investigating issues that are difficult to examine because they are rare events or involve complex multi-attribute situations (Ganong and Coleman, 2006; Wallander, 2009). Surveys, on the other hand, offer the possibility of gathering a wide range of information on context and attitudes. Although this design has clear advantages compared to single-method research design, one has to keep in mind that we asked managers to assess hypothetical situations. In addition, in our study the applicants' pool was limited to early retirees. This lowered the realism of the hiring situation. In real-life hiring participants may act or decide differently. Low hiring scores can be due to managerial comparison to other (younger) applicants, who are a natural part of the general applicants' pool.

Labour market participation of older workers is a growing concern of many governments. Our findings show that age norms hamper the return to the labour force. Chances of early retirees in the labour market are lower at older ages, and managers are negatively preoccupied about hiring anyone beyond a certain age. Yet, organisational forces and the individual characteristics of applicants also affect the choices managers make, showing that hiring of early retirees is a complex process. An important question is to what extent age norms will change in the near future. Will they change rapidly as a result of the changing public pension ages in Europe or will they remain unaffected? Also, will their change also apply to employees? Liefbroer (2009) showed that employees hold specific norms about appropriate timing of labour force exit. Age norms are thus woven in the broader context of work relations, indicating its complex impact on labour force outcomes.

\section{Note}

1. For distinctions between respondents' professions see: www.lissdata.nl/dataarchive/study_ units/view/145.

\section{References}

Bargh, J.A., Chen, M. and Burrows, L. (1996), “Automaticity of social behavior: direct effects of trait construct and stereotype activation on action", Journal of Personality and Social Psychology, Vol. 71 No. 2, pp. 230-244.

Becker, G.S. (1975), Human Capital: A Theoretical and Empirical Analysis with Special Reference to Education, 2nd ed., Columbia University Press, New York, NY. 
Bendick, M., Jackson, C.W. and Romero, J.H. (1997), "Employment discrimination against older workers - an experimental study of hiring practices", Journal of Ageing and Social Policy,

\section{Hiring retirees} Vol. 8 No. 4, pp. 25-46.

Berger, E.D. (2009), "Managing age discrimination: an examination of the techniques used when seeking employment”, The Gerontologist, Vol. 49 No. 3, pp. 317-332.

Bruce, D., Holtz-Eakin, D. and Quinn, J. (2000), "Self-employment and labor market transitions at older ages", Working Paper 2000-13, Center for Retirement Research at Boston College, available at: http://escholarship.bc.edu/retirement papers/33 (accessed March 29, 2010).

Chiu, W.C., Chan, A.W., Snape, E. and Redman, T. (2001), "Age stereotypes and discriminatory attitudes towards older workers: an East-West comparison", Human Relations, Vol. 54 No. 5, pp. 629-661.

Coleman, J. (1990), Foundations of Social Theory, Belknap Press, Cambridge, MA.

DiNatale, M. (2001), "Characteristics of and preference for alternative work arrangements, 1999", Monthly Labor Review, Vol. 124 No. 3, pp. 28-49.

Eijs, P.v. and Heijke, H. (2000), "Mismatch between occupation and education and the costs and benefits of job related training", in Heijke, H. and Muysken, J. (Eds), Education and Training in a Knowledge-Based Economy, Macmillan, London, pp. 159-189.

Ekerdt, D.J. (2010), "Frontiers of research on work and retirement", Journals of Gerontology Series $B$ - Psychological Sciences and Social Sciences, Vol. 65 No. 1, pp. 69-80.

Elster, J. (1989), "Social norms and economic-theory", Journal of Economic Perspectives, Vol. 3 No. 4, pp. 99-117.

Etzioni, A. (2000), "Social norms: internalization, persuasion, and history", Law \& Society Review, Vol. 34 No. 1, pp. 157-178.

European Commission (2006), Employment in Europe 2006, European Commission, Brussels.

Finkelstein, L.M. and Burke, M.J. (1998), "Age stereotyping at work: the role of rater and contextual factors on evaluations of job applicants", Journal of General Psychology, Vol. 125 No. 4, pp. 317-345.

Finkelstein, L.M., Burke, M.J. and Raju, N.S. (1995), "Age-discrimination in simulated employment contexts - an integrative analysis", Journal of Applied Psychology, Vol. 80 No. 6, pp. 652-663.

Fugate, M., Kinicki, A.J. and Ashforth, B.E. (2004), "Employability: a psycho-social construct, its dimensions, and applications", Journal of Vocational Behavior, Vol. 65 No. 1, pp. 14-38.

Ganong, L.H. and Coleman, M. (2006), "Multiple segment factorial vignette designs", Journal of Marriage and the Family, Vol. 68 No. 2, pp. 455-468.

Hassell, B.L. and Perrewe, P.L. (1995), "An examination of beliefs about older workers do stereotypes still exist”, Journal of Organizational Behavior, Vol. 16 No. 5, pp. 457-468.

Henkens, K. (2005), "Stereotyping older workers and retirement: the managers' point of view", Canadian Journal on Aging - Revue Canadienne Du Vieillissement, Vol. 24 No. 4, pp. 353-366.

Hilton, J.L. and von Hippel, W. (1996), "Stereotypes”, Annual Review of Psychology, Vol. 47, pp. 237-271.

Horne, C. (2003), "The internal enforcement of norms", European Sociological Review, Vol. 19 No. 4, pp. 335-343.

Hox, J.J. (2002), Multilevel Analysis: Techniques and Applications, Lawrence Erlbaum Associates, Mahwah, NJ. 
JMP $28,7 / 8$

904
Jones, D.A. and McIntosh, B.R. (2010), "Organizational and occupational commitment in relation to bridge employment and retirement intentions", Journal of Vocational Behavior, Vol. 77 No. 2, pp. 290-303.

Kalleberg, A.L., Knoke, D., Marsden, P.V. and Spaeth, J.L. (1996), Organizations in America: Analyzing their Structures and Human Resource Practices, Sage Publications, Thousand Oaks, CA.

Karpinska, K., Henkens, K. and Schippers, J. (2011), “The recruitment of early retirees: a vignette study of the factors that affect managers' decisions”, Ageing \& Society, Vol. 31 No. 4, pp. 570-589.

Kim, S. and Feldman, D.C. (2000), "Working in retirement: the antecedents of bridge employment and its consequences for quality of life in retirement", Academy of Management Journal, Vol. 43 No. 6, pp. 1195-1210.

Koppes, L.L.J., De Vroome, E.M.M., Mol, M.E.M., Janssen, B.J.M. and van den Bossche, S.N.J. (2009), Nationale Enquête Arbeidsomstandigheden 2008 (National Labour Force Survey 2008), Nederlandse Organisatie voor Toegepast Natuurwetenschappelijk Onderzoek, Delft.

Lawrence, B.S. (1996), "Organizational age norms: why is it so hard to know one when you see one?”, Gerontologist, Vol. 36 No. 2, pp. 209-220.

Lee, J.A. and Clemons, T. (1985), "Factors affecting employment decisions about older workers", Journal of Applied Psychology, Vol. 70 No. 4, pp. 785-788.

Leeuw, E.D., Hox, J. and Dillman, D.A. (2008), International Handbook of Survey Methodology, Lawrence Erlbaum Associates, New York, NY.

Liefbroer, A.C. (2009), "European opinions on the timing of retirement", available at: www. multilinks-project.eu/uploads/papers/0000/0024/Second_Policy_Brief_MULTILINKS.pdf (accessed December 12, 2011).

Liefbroer, A.C. and Billari, F.C. (2010), "Bringing norms back in: a theoretical and empirical discussion of their importance for understanding demographic behaviour", Population, Space and Place, Vol. 16 No. 4, pp. 287-305.

Loretto, W., Duncan, C. and White, P.J. (2000), "Ageism and employment: controversies, ambiguities and younger people's perceptions", Ageing and Society, Vol. 20 No. 3, pp. 279-302.

Marsden, P.V. and Garman, E. (2001), "Social networks, job search and recruitment", in Berg, I.E. and Kalleberg, A.L. (Eds), Sourcebook of Labor Markets: Evolving Structures and Processes, Kluwer Academic/Plenum Press, New York, NY, pp. 476-502.

Maurer, T., Barbeite, F., Weiss, E. and Lippstreu, M. (2007), "New measures of stereotypical beliefs about older workers' ability and desire for development. Exploration among employees aged 40 and over", Journal of Managerial Psychology, Vol. 23 No. 4, pp. 395-418.

Munnell, A.H. and Sass, S.A. (2008), Working Longer. The Solution to the Retirement Income Challenge, The Brookings Institution, Washington, DC.

Ng, T.W.H. and Feldman, D.C. (2008), "The relationship of age to ten dimensions of job performance", Journal of Applied Psychology, Vol. 93 No. 2, pp. 392-423.

Phelps, E.S. (1972), "Statistical theory of racism and sexism", American Economic Review, Vol. 62 No. 4, pp. 659-661.

Posthuma, R.A. and Campion, M.A. (2009), "Age stereotypes in the workplace: common stereotypes, moderators, and future research directions", Journal of Management, Vol. 35 No. 1, pp. 158-188. 
Remery, C., Henkens, K., Schippers, J. and Ekamper, P. (2003), "Managing an aging workforce and a tight labor market: views held by Dutch employers", Population Research and Policy Review, Vol. 22 No. 1, pp. 21-40.

Rossi, P.H. and Anderson, A.B. (1982), "Measuring social judgments: the factorial survey approach”, in Rossi, P.H. and Nock, S.L. (Eds), Measuring Social Judgments: The Factorial Survey Approach, Sage Publications, Beverly Hills, CA, pp. 15-67.

Settersten, R.A. (1998), "Time, age, and the transition to retirement: new evidence on life-course flexibility?", International Journal of Aging \& Human Development, Vol. 47 No. 3, pp. 177-203.

Settersten, R.A. and Hagestad, G.O. (1996), "What's the latest? II. Cultural age deadlines for educational and work transitions", The Gerontologist, Vol. 36 No. 5, pp. 602-613.

Spence, M. (1973), “Job market signaling”, Quarterly Journal of Economics, Vol. 87 No. 3, pp. 355-374.

Standaard Beroepenclassificatie (2010), available at: www.cbs.nl/NR/rdonlyres/6221F84DBEDD-4B0C-B9ED-ADF076E4D769/0/2010sbcclassificatieschema.pdf

Statistics Netherlands (2009), “Arbeidsdeelname: 15 jaar of ouder”, StatLine.

Taylor, P. (2008), “Are European older workers on the verge of a 'golden age' of employment opportunities?”, in Chiva, A. and Manthorpe, J. (Eds), Older Workers in Europe, Open University Press, Maidenhead, pp. 38-52.

Taylor, P. and Walker, A. (1998), "Employers and older workers: attitudes and employment practices", Ageing and Society, Vol. 18, pp. 641-658.

Taylor, P.E. and Walker, A. (1994), "The aging workforce - employers' attitudes towards older-people", Work Employment and Society, Vol. 8 No. 4, pp. 569-591.

Thurow, L.C. (1975), Generating Inequality: Mechanisms of Distribution in the US, Basic Books, New York, NY.

van Dalen, H.P. and Henkens, K. (2002), "Early-retirement reform: can it and will it work?", Ageing and Society, Vol. 22 No. 2, pp. 209-232.

Van Dalen, H.P., Henkens, K. and Schippers, J. (2010), "Productivity of older workers: perceptions of employers and employees", Population and Development Review, Vol. 36 No. 2, pp. 309-330.

van Dalen, H.P., Henkens, K., Lokhorst, B. and Schippers, J. (2009), "Herintreding van vroeggepensioneerden”, Onderzoeksrapport 9-9-2009, Raad voor Werk en Inkomen, Den Haag.

van Solinge, H. and Henkens, K. (2007), "Involuntary retirement: the role of restrictive circumstances, timing, and social embeddedness", Journals of Gerontology Series B Psychological Sciences and Social Sciences, Vol. 62 No. 5, pp. 295-303.

von Bonsdorff, M.E., Shultz, K.S., Leskinen, E. and Tansky, J. (2009), "The choice between retirement and bridge employment: a continuity theory and life course perspective", International Journal of Aging \& Human Development, Vol. 69 No. 2, pp. 79-100.

Wallander, L. (2009), "25 years of factorial surveys in sociology: a review", Social Science Research, Vol. 38 No. 3, pp. 505-520.

Wang, M. and Shultz, K.S. (2010), "Employee retirement: a review and recommendations for future investigation", Journal of Management, Vol. 36 No. 1, pp. 172-206.

Wang, M., Zhan, Y., Liu, S. and Shultz, K.S. (2008), "Antecedents of bridge employment: a longitudinal investigation”, Journal of Applied Psychology, Vol. 93 No. 4, pp. 818-830.

Weckerle, J.R. and Shultz, K.S. (1999), "Influences on the bridge employment decision among older USA workers", Journal of Occupational and Organizational Psychology, Vol. 72, pp. 317-329. 
JMP

$28,7 / 8$

906

\section{About the authors}

Kasia Karpinska studied sociology at Utrecht University and obtained her PhD degree at Utrecht University School of Economics and The Netherlands Interdisciplinary Demographic Institute (NIDI). Her research interest covers employers' behaviour toward older workers. Kasia Karpinska is the corresponding author and can be contacted at: kasiakarpinska@hotmail.com

Kène Henkens is a sociologist and Head of the Social Demography Department of The Netherlands Interdisciplinary Demographic Institute (NIDI). He is Professor of Sociology of Retirement at the University of Amsterdam and is affiliated with Netspar. He has published extensively on issues regarding the labour supply in an ageing workforce. His main research interest is in the area of an ageing workforce and retirement.

Joop Schippers is Professor of Labour Economics and the Economics of Equal Opportunity at Utrecht University. He has published a series of books and articles on male-female wage differences, human capital investments, labour market flexibility and organisational behaviour with respect to women and older workers.

To purchase reprints of this article please e-mail: reprints@emeraldinsight.com Or visit our web site for further details: www.emeraldinsight.com/reprints 